\title{
Michael Serres
}

\section{A platóni dialógus és az absztrakció interszubjektív keletkezése}

Ismerjük a szimbólum fogalmával kapcsolatos nagy logikai vitákat. ${ }^{1}$ Anélkül, hogy belemennénk a hilbertiánus típusú realistákat, a Quine-követő nominalistákat, a lengyel iskola képviselőit és a többieket elválasztó érvek érdemi tárgyalásába, most csupán, eltérő irányt felvéve, a kérdés egyik szeletét érintjük.

Amikor kommunikálni kívánok egy másik emberrel, egy sor technika áll a rendelkezésemre, legyenek régiek vagy újak, sőt pillanatnyilag az sem érdekes, hogy természetesek vagy kiagyaltak: nyelvek, írások, az üzenetek felhalmozásának, átadásának, sokszorosításának eszközei, hangszalagok, telefon, nyomtatás és így tovább. Az írás a legegyszerűbbek, ugyanakkor a leggazdagabbak közül való, hiszen a segítségével felhalmozhatom, átadhatom és sokszorosíthatom az információt. Ám mielőtt még rátérnénk e kérdésekre, amelyekhez a stílus, az elbeszélés vagy az érvelés elrendezése és más efféle problémák csatlakoznak, a grafizmusról van szó: az írás mindenekelőtt rajzolat, ideogramma vagy konvencionális ábra. Azt máris elismerhetjük, hogy írott kommunikáció csak akkor jöhet két személy között, ha az írásosság egyazon módozatában

${ }^{1}$ Ld. Roger Martin Logique contemporaine et formalisation 24-30. 
járatosak ${ }^{2}$, ha az értelem kódolására és dekódolására kialakított eszközeik ugyanarra a kulcsra járnak.

Vegyünk tehát kiindulásképpen egy írott üzenetet: mondjuk úgy, hogy csak akkor érthető, ha a befogadó birtokában van a rajzolat kulcsának. Ez a befogadás feltétele, méghozzá lényegi feltétele. Van azonban egy másik is, amely jóllehet pusztán a körülményektől függ, mégis nem kevésbé méltó az elemzésre. Az írnoknak a lehető legjobban kell elkészíteni a rajzolatot. Mit jelent ez? Először is azt, hogy az ábra lényegi, értelemmel teljes jegyeket hordoz: a betűk (normalizált) alakja, a betü- majd szósorok megfelelő (morfológiai és szintaktikai szabályok szerinti) kialakítása stb.; azután azt, hogy nem lényegi, véletlenszerü, a jelentéshez nem tartozó jegyek járulnak hozzá, amelyek függenek az írás készítőjének készségétől, ügyetlenségétől, kultúrájától, hajlamaitól, betegségétől...: az írásmód megremegései, a rajzolat fogyatékosságai, a helyesírási hibák és társaik. Az első feltétel ortogrammát és kalligrammát kíván meg; márpedig ilyesmi sohasem vagy majdnem sohasem áll elő. ${ }^{3}$ A kalligramma óvja a formát az esetleges zavarokkal szemben: s amennyiben a logikusokat érdeklődésük a formához köti, úgy lehetséges olyan

\footnotetext{
${ }^{2}$ Könnyűszerrel kimutatható az is, hogy egyetlen kommunikációs eszköz mint olyan sem lehet univerzális: éppen ellenkezőleg, mindegyikük regionális, azaz egy nyelvvel izomorf. A nyelvi kommunikáció tere (amely tehát egyben mindenfajta kommunikáció tere) nem izotróp. Létezik mindazonáltal egy tárgy, ami univerzális kommunikáns, illetve univerzális kommunikált: a technikai tárgy általában véve. Ezért tarthatjuk úgy, hogy a történelem hajnalán az első diffúzió vele esett meg: kommunikációs tere izotróp. De nem szabad ámítani magunkat: most a történelem-előtti meghatározásáról van szó. A történelem a regionális nyelvvel, az anizotróp kommunikációs térrel veszi kezdetét. Innen a három állapot törvénye: technológiai izotrópia, nyelvészeti anizotrópia, nyelvitechnikai izotrópia. Nemsokára a harmadiknak is be kell következnie.

${ }^{3}$ Aligha szükséges hangsúlyozni, hogy a nyomtatás elsődleges jótéteménye az, hogy az olvasónak immár nem kell epigráfusnak is lennie. A nyomtatott szöveg kalligramma (jóllehet nem mindig ortogramma). Magától értetődik, hogy a második jótétemény a mesterséges sokszorosíthatóságban áll.
} 
érdeklődés is, amely a patológiához, azaz a kakográfiához füződik. A grafológia a hamisság ama tudománya (vagy az a hamis tudomány), amely a kakográfia pszichológiai hajtóerőinek kötelezte el magát: de vajon beszélhetünk-e tisztán ez utóbbiról, lehet-e szó tisztán a tiszta szennyeződésről?

A kommunikáció patológiája nem kizárólag az írás ügye. $A$ beszélt nyelvben éppúgy nyomára akadhatunk: dadogás, baki, tájszólás, hangképzési hibák, kakofónia. Hasonlóképpen a kommunikáció technikai segédeszközeinél: alapzaj, vízcsobogás, áthallások, paraziták, szinkronkiesés mintha csak a gondolategységek volnának akcidentálisak, a lényegi viszont, a kommunikáció számára, az alapzaj volna.

Elfogadva a tudományos tradíció szóhasználatát, nevezzük zajnak a zavaró áthallások ama jelenségcsoportját, amely a kommunikáció akadályaként nyilvánul meg. A kakográfia ezek szerint az a zaj, amely az írásosság esetén lép fel, jobban mondva az írásosság egyfelöl valamiféle lényegi formát, másfelől valamiféle - lényegi vagy alkalmi jellegü zajt hordoz: rosszul írni annyi, mint megmeríteni a grafikai üzenetet ebben az olvasást akadályozó zajban, ami tehát epigráfussá változtatja az olvasót. Vagy inkább mondjuk azt, hogy az írás az a kockázatos vállalkozás, amely megkísérel formát vinni a zürzavarba. S ugyanígy, az orális kommunikáció sem egyéb, mint merész kísérlet arra, hogy értelmet alkossunk a zajból. Egyes nyelvtudósok szemében 4 ezek a jelenségek olyannyira fontosnak tüntek, hogy őket alapul véve nem haboztak átalakítani a dialógusról alkotott felfogásunkat: eszerint a kommunikáció egyfajta játék két szövetségesnek tekintett résztvevő között, akik összefognak 
az áthallás és zavarás jelenségei, mi több, azon személyek ellen, akiknek valamiért érdekében áll a kommunikáció megzavarása. 5 A résztvevők tehát nem szembenálló felek, mint azt a müvelet hagyományos, dialektikus felfogása vélte, hanem éppen hogy egyazon táborhoz tartoznak, érdekazonosság fűzi őket össze: vállvetve küzdenek a zaj ellen. A kakográfus és az epigráfus, a rosszul beszélő és a hallgató kölcsönösen átvehetik egymás szerepét a dialógusban, ahol a kibocsátó befogadóvá, a befogadó kibocsátóvá válik valamiféle ritmus szerint, s végül kitűnik, hogy együttes küzdelmük egy közös ellenség ellen irányul. Dialógusba bocsátkozni nem más, mint tételezni egy harmadikat, majd megkísérelni kívül rekeszteni őt; a sikeres kommunikáció annyi, mint a kizárt harmadik. A legmélyebb dialektikai probléma nem a másik problémája, aki csupán az ugyanaz változatossága - avagy változata -, hanem a harmadik ember problémája. Ezt a harmadik embert neveztük már Démonnak is, ő a zaj megszemélyesítője.

A dialógusnak ez a felfogása közvetlenül alkalmazható egyik-másik nevezetes filozofémára, amely így soha nem hallott jelentésre tesz szert. Az Elmélkedések az első filozófiáról például kiválóan magyarázható a szóban forgó elvek mentén: célja az, hogy fellelje a másikat, szövetségesül az ugyanaz számára, hogy elüzhessék a harmadik embert. 6 Pillanatnyilag maradjunk csak a platóni

\footnotetext{
${ }^{4}$ Például B. Mandelbrojt és Jakobson. Ld. Norbert Wiener: The Human Use of Human Beings, IV. és XI. fejezet.

${ }^{5}$ Amiként az írott kommunikáció is az érdek- és szándékszövetséget kötött lejegyző és az olvasó harca a kommunikáció akadályaival szemben: a tengerbe vetett palack esete.

${ }^{6}$ Közzé fogjuk tenni a vonatkozó értelmezést, melynek eredményeként nagyjából az a gondolat áll elő, hogy a descartes-i szöveg a fizikai kísérlet lehetőségfeltételét alkotja, ami ily módon tehát metafizikának bizonyul. A platóni szövegek ezt megelőzően a matematikai ideáció lehetőségfeltételeit biztosították.
} 
dialógusoknál: A bábáskodó módszer voltaképpen a szülés levezetésében egyesíti a kérdezőt és a válaszolót. A dialektika mindkét résztvevőt azonos oldalon helyezi el, együttesen küzdenek egy igazság megszületéséért, amelynek kérdésében képesek egyetértésre jutni, egyszóval a fáradozások tétje a sikeres kommunikáció. Bizonyos értelemben együttesen küzdenek meg a zavarral, a démonnal, a harmadik emberrel. A harc, mint tudjuk, nem mindig vezet diadalra: az aporetikus dialógusok esetében a győzelmet a zaj hatalma ragadja el, de az összecsapás a többiben is igen heves, és ez is ama bizonyos harmadik erejét mutatja. Lassanként visszalopódzik a derü, de csak ha az ördögüzés már mindörökre (?) eredményesnek bizonyult.

Nem férne bele e tanulmány keretei közé, ha a maga teljes gazdagságában ki akarnánk fejteni a harmadik témáját a platóni dialógusokban; túl messzire vezetne, valójában máris meglehetősen messzire kalandoztunk premisszáinktól. Ám korántsem oly messzire, ahogyan tűnhet.

Térjünk vissza logikához, ezáltal pedig az íráshoz. A logikus számára egy szimbólum egyenlő egy rajzolattal, egy ábrával, amit egy kréta segítségével megformálok a táblán. Egy adott szimbólum az egymást követő formulákban többször előfordulhat. A matematikusok mindannyian és egyöntetüen osztoznak abban, hogy "ugyanazt" a szimbólumot ismerik fel a maga két vagy több előfordulása során. És mégis, minden egyes előfordulás, bármilyen legyen is, különbözik a többitől, méghozzá éppen az írásosság következtében: megremeg a húzott vonal, elcsúszik a mozdulat stb. A logikus ettől kezdve nem az itt és most a táblára rajzolt konkrét ábra alapján okoskodik, hanem, miként Tarski mondotta, ama tárgyak osztálya 
alapján, amelyek egyazon formával bírnak: a szimbólum eszerint egy absztrakt létező, amit a kérdéses ábra csupán felidéz. Ha merészelhetek így fogalmazni, e létező felismerése a gráfok homeomorfiája révén megy végbe. A felismerés feltételezi, hogy a formát megkülönböztetjük attól, amit fentebb kakográfiának neveztem. A matematikus nem lát itt semmi nehézséget, $s$ a további szószaporítás az ő szemében általában merőben haszontalannak látszik.

Ám ahol a tudós türelmét veszítve feszengeni kezd, a filozófus megálljt int, $s$ azt tudakolja, miként alakulna ez a kérdésfeltevés, ha a matematika nem létezne. Látja, hogy a matematikusok mindannyian kiegyeznek: készek ugyanazt a változatlan formát felismerni az azt megidéző írásosság eltérő változataiban. Márpedig azt ő is tudja, akárcsak mindenki más, hogy egyetlen írásmód sem hasonul a másikhoz; s ha felmerül a kérdés, hogy az írásban mekkora rész jut a formának és mekkora a kakográfiának, akkor bizony be kell látni, hogy a zaj, mint némelyek mondják majd, elborítja az egészet. Mindebből pedig, s ha számot vet a korábban mondottakkal, arra a következtetésre jut, hogy egy és ugyanazon aktus hatálya alatt történik meg az absztrakt létező felismerése a konkrét ismertetőjegyek előfordulásaiban és az egyetértés megszületése e felismerés vonatkozásában. Más megfogalmazásban: a kakográfia megszüntetésének aktusa, a zaj kiküszöbölésének kísérlete egyszerre feltétele az absztrakt forma megragadásának és a kommunikáció sikerének. A matematikus azért türelmetlen, mert egy olyan társadalomban gondolkodik, amely, amennyire csak lehet, diadalmaskodott a zaj felett, méghozzá oly régóta már, hogy meglepetést okoz, ha e probléma újból felmerül. $A$ "mi" világában és az absztrakció világában gondolkodik, márpedig ez két izomorf világ, sőt az is meglehet, hogy azonosak. Hiszen az absztrakt 
matematika szubjektuma nem más, mint az a "mi", aki az ideális államot lakja - és vessük közbe: ebből is látható, hogy Platón és Leibniz nem voltak idealisták -, vagyis a zajtól a legnagyobb mértékben megtisztított kommunikáció városát. Formalizálni, általában véve, annyit tesz, mint befutni azt a pályát, amely a konkrét gondolkodásmódoktól egy absztrakt formáig (vagy formákig) vezet; egyszersmind pedig megvalósítani a lehető legoptimálisabb zajszűrést. Rádöbbenünk tehát, hogy a matematika birodalmában a zaj csupán a majdnem tökéletesen megvalósult kommunikáció, a manthanein elkerülhetetlen hordaléka lehet, hogy e birodalomban kizárt a harmadik, a démont majdhogynem végérvényesen elüzték. Ha matematika nem létezne, az ördögűzést kezdhetnénk előröl.

A demonstráció megismétlődik. A logika hajnalán, mármint a logika egyszerre történelmi és logikai kezdeteinél, egyszersmind a matematika logikai kezdeteinél Hilbert és mások újra végigkövették az absztrakt idealitásokkal kapcsolatos platóni eljárást, ami a matematika - történelmi - hajnalán a görög csoda egyik feltételét képezte. Csakhogy a tárgyalás a mi esetünkben igencsak csonka, hiszen mi már nem tehetjük zárójelbe a matematika történelmi létezésének megkerülhetetlen tényét. Platónnál ezzel szemben az érvelés teljes volt és kimerítő: egybeesett benne az absztrakt forma felismerése és a dialógus sikerének problémája. Amikor kimondom az "ágy" szót, nem egy ilyen és ilyen ágyról, az enyémről vagy a tiédről, erről vagy egy másikról beszélek, hanem az ágy ideáját idézem fel; amikor négyzetet és átlót rajzolok a homokba, a legkevésbé sem erről a reszketeg, szabálytalan és pontatlan rajzolatról kívánok szólni, hanem az átló és a négyzet ideális formáját idézem meg általa: kiküszöbölöm azt, ami empirikus, anyagtalanítom az okoskodást. S miközben így teszek, megalapozom egy 
tudomány lehetőségét, a szigor és az igazság nevében járok el, de ugyanakkor az egyetemes, a magábanvaló Egyetemes nevében is. Miközben így teszek, kiküszöbölöm mindazt, ami elfedi a formát, a kakográfiát, a zavart és a zajt, lehetővé teszem egy tudomány kibontakozását abban, ami számunkra Egyetemes. A matematikai forma egyszerre a magábanvaló Egyetemes és a számunkra való Egyetemes: és ezért van, hogy az elsődleges erőfeszítés, amely a kommunikáció sikerére tör a dialógusban izomorf azzal az erőfeszítéssel, amely megállapítja a formát az empirikus megvalósulástól függetlenül. Ez az empirikus megvalósulás az a bizonyos harmadik a forma esetében, ez jelenti a zavart és a zajt a számára, és ennek folytonos beszüremkedése okozza az első dialógusok aporetikusságát. A dialógus dialektikus módszerének ugyanaz a forrásvidéke, mint a matematikai módszernek, mely utóbbi egyébiránt ugyancsak a dialektika nevét visel.

Az empirikus kizárása egyenlő a különbségtétel, az ugyanazt elborító mások sokaságának kizárásával. Íme a matematizáció, a formalizáció első mozzanata. Ebben az értelemben a modern logikusok szimbólummal kapcsolatos megfontolásai analógiát mutatnak a homokba rajzolt geometriai forma platóni tárgyalásával: ki kell küszöbölni a kakográfiát, a meghúzott vonal egyenetlenségét, a rajzolat szeszélyességét, a mozdulat esetlenségét, azokat a véletlen körülményeket, amelyek miatt egyetlen ábra sem lesz egészen pontosan olyan, mint a másik. Aminthogy az érzékelt dolog is végletes megkülönböztethetőséget rejt: külön szót kellene találni minden egyes körhöz, minden szimbólumhoz, minden fához és galambhoz; aztán külön szót a tegnap, a ma és a holnap számára; aztán külön-külön szót attól függően, hogy te érzékeled az illető dolgot, vagy én, hogy valamelyikünk éppen dühös-e, esetleg sárgaságban 
szenved, és így tovább a végtelenségig. Az empirizmus legvégső következményeként az értelem tökéletesen elmerül a zajban, elszemcsésedik a kommunikáció tere 7 , a dialógus felett a kakofónia hirdet ítéletet: a kommunikáció átvitele örökös átalakításként valósul meg. Szigorúan véve tehát ami empirikus, az a lényegi és esetleges zaj. Mindenekelőtt az empirista a kizárandó "harmadik ember", a kizárandó harmadik az empíria; és ez a démon bizonyul minden démonok legerősebbikének, hiszen elég, ha kinyitjuk szemünket és fülünket, máris látjuk, hogy ő a világ ura. $8 \mathrm{Ha}$ lehetővé akarjuk tenni a dialógust, be kell hunynunk szemünket, be kell fognunk fülünket a szirének hangja és szépsége elől. Egyazon mozdulattal megszüntetjük a hallást és a zajt, a látványt és a mindig tökéletlen rajzolatot; vagyis egy csapásra felfogjuk a formát és megértjük önnön magunkat. És ha megteszünk még egy lépést, elmondhatjuk, hogy a matematika görög csodájának egyidőben - egyazon történelmi, logikai, reflexív időben kellett megszületnie a dialógus filozófiájával, a dialógusban kibomló filozófiával.

Az a kötelék, amely a platonizmusban összefüzi a dialektikus módszert - mármint a kommunikáció dialektikus módszerét - és az absztrakt idealitások geometriai stílusú,

\footnotetext{
${ }^{7}$ Ebből következően belátható, hogy amennyiben a megkülönböztethetetlenség elvét elfogadjuk, úgy el kell fogadnunk a Leibniz által következetesen képviselt álláspontot, miszerint a monászok nem hallanak és nem hallatnak magukról, ajtó és ablak nélkül valók. Ha Zénónnak igaza volt, az Eleátáknak el kell némulniuk.

${ }^{8}$ Amiként az is jól látható, hogy valahányszor egy empirista és egy racionalista - mondjuk Locke és Leibniz - vitázik egymással, mindig az empiristának volna igaza, feltéve hogy a matematika nem létezne. Az empirizmus válik az igaz filozófiává, mihelyt a matematika zárójelek közé kerül. Még mielőtt a matematika elnyerte volna kényszerítő tekintélyét, s hogy elnyerhesse azt, akarni kellett, hogy ne halljuk meg Prótagorasz és Kalliklész szavát: éspedig azért, mert igazuk volt. Az az érv, amelyet Leibniz fogalmazott meg Locke-kal szemben, hogy tudniillik ez utóbbi nem ismeri a matematikát, nem egyszerűen argumentum ad hominem, hanem az egyetlen lehetséges logikus védekezés.
} 
mind kifinomultabb, letisztultabb ábrázolását, nem valamiféle eszmetörténeti véletlennek, de nem is a filozófus személyes elhatározásának köszönhető: a dolgok természete írta elő. Az ideális forma kibontakoztatása azt jelenti, hogy megszabadítjuk azt az empíriától és a zajtól; a zaj nem más, mint az üzenet empirikussága, ahogyan az empíria pedig a forma zajossága. Ebből a szempontból az a kevéske szokratikus dialógus prematematikainak minősül, miként az volt hajdan egy négyzet alakú búzatábla megmérése is a Nílus völgyében.

[Sutyák Tibor fordítása] 